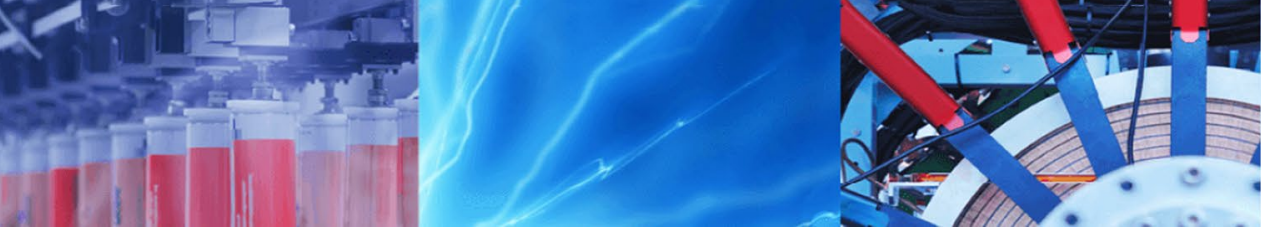

Research Article

\title{
Effect of moisture concentration on electrodeposition of aluminum in dimethylsulfone
}

\author{
Sangjae $\mathrm{Kim}^{1}\left[\right.$ [D $\cdot$ Kensuke Kuroda ${ }^{2} \cdot$ Masazumi Okido $^{2}$
}

(c) Springer Nature Switzerland AG 2018

\begin{abstract}
The influence of moisture on Al electrodeposition was investigated in $23.3 \mathrm{~mol} \% \mathrm{AlCl}_{3}-\mathrm{DMSO}_{2}$ bath at $403 \mathrm{~K}$. Cyclic voltammetry measurement and electrodeposition at constant current were carried out in baths containing 67-174 ppm moisture. The deposits obtained under $40 \mathrm{~mA} \mathrm{~cm}^{-2}$ for $1 \mathrm{~h}$ was characterized in terms of their surface appearance, surface microstructure, and cross section in SEM observation, XRD analysis and surface hardness, and film thickness (current efficiency). In addition, NMR spectroscopy was used to clarify the effect of moisture on the relative abundance of $\mathrm{Al}\left(\mathrm{DMSO}_{2}\right)_{3}^{3+}$ and $\mathrm{AlCl}_{4}^{-}$species in the bath. When the $\mathrm{AlCl}_{3}-\mathrm{DMSO}_{2}$ bath was kept at $403 \mathrm{~K}$ in the glove box, its moisture content decreased gradually up to $5 \mathrm{~h}$, and increased between 6 and $72 \mathrm{~h}$ with the elapse of heating time. A high current efficiency of c.a. $100 \%$ was observed, the low surface hardness was improved, and the surface was uniform for Al deposits obtained after 5 and $6 \mathrm{~h}$ or drying when the abundance of $\mathrm{Al}\left(\mathrm{DMSO}_{2}\right)_{3}^{3+}$ was relatively high.
\end{abstract}

Keywords Electrodeposition · Aluminum · Nuclear magnetic resonance · Dimethylsulfone $\cdot$ Moisture concentration

\section{Introduction}

Aluminum (Al) is widely used in aircrafts, aerospace, optical, and automobile industries due to its excellent corrosion resistance and physicochemical properties. Several methods are now available to obtain Al deposits in ionic liquids [1-9], molten salts [10-12], physical vapor deposition $[13,14]$, chemical vapor deposition, spray coating [15, $16]$, cementation $[17,18]$, sputtering $[19,20]$, hot dipping [21, 22], and electrodeposition [23-25].

As $\mathrm{Al}$ is highly reactive $\left(E^{\circ}=-1.67 \mathrm{~V}\right.$ vs. $\left.\mathrm{NHE}\right)$, it cannot be electrodeposited in aqueous solutions $[24,26]$. In recent years, the development of ionic liquids has opened a door for the electrodeposition of Al and many other elements, such as $\mathrm{Mg}, \mathrm{Ti}, \mathrm{Ta}, \mathrm{Si}$, and $\mathrm{Ge}$ that cannot be obtained from aqueous solutions at moderate temperatures. Whereas the electrolysis of alumina used to be the only way to produce $\mathrm{Al}$ [27], the electrodeposition of Al and its alloys in chloroaluminate ionic liquids, which are considered firstgeneration ionic liquids has been intensively studied. Also, coating methods using organic compounds such as nonaqueous solvent and ionic fluid have been examined. These compounds are nonvolatile ionic solvents: $\mathrm{AlCl}_{3}$-N-ethylpyridinium bromide, $\mathrm{AlCl}_{3}$-N-ethylpyridinium chloride, $\mathrm{AlCl}_{3}$-1,3-dialkylimidazolium chloride, and $\mathrm{AlCl}_{3}$-1-butyl-1-methyl pyrrolidinium $[8,28,29]$. Recently, these ionic liquids have been proposed as alternative electrodeposition solutions [30-32]. In comparison with ionic liquids, a lower vapor pressure, a higher electric conductivity, a wider electrochemical window, and its high flammability hinders its widespread use in many applications. To solve this problem, $\mathrm{AlCl}_{3} /$ dimethylsulfone has been employed for electrodeposition at low temperature [33-41]. Dimethylsulfone $\left(\mathrm{DMSO}_{2}\right.$ or $\left.\left(\mathrm{CH}_{3}\right)_{2} \mathrm{SO}_{2}\right)$ is a nontoxic white crystalline powder with high solubility in $\mathrm{AlCl}_{3}$ and in organic solvents such as acetone and ethyl alcohol,

Sangjae Kim, sangjai88@gmail.com | 1 Department of Materials Science and Engineering, Graduate School of Engineering, Nagoya University, Nagoya 464-8603, Japan. ${ }^{2}$ Institute of Materials and Systems for Sustainability, IMaSS, Nagoya University, Nagoya 464-8603, Japan.

SN Applied Sciences (2019) 1:53 | https://doi.org/10.1007/s42452-018-0067-y 
and it exhibits a low melting point of $382 \mathrm{~K}$ [42]. Moreover, compared to other ionic liquids and molten salts, electrodeposition in an $\mathrm{AlCl}_{3}-\mathrm{DMSO}_{2}$ bath is an economic and straightforward technique that produces a uniform and smooth $\mathrm{Al}$ electrodeposit. In addition, it is possible to electroplate $\mathrm{Al}$ at close to $380 \mathrm{~K}$ in an $\mathrm{AlCl}_{3}-\mathrm{DMSO}_{2}$ bath $[42,43]$. Previous studies have clarified conditions for the electrodeposition of a dense and smooth Al film from this bath. In the $\mathrm{AlCl}_{3}-\mathrm{DMSO}_{2}$ bath, the $\mathrm{Al}$ ions are present as $\mathrm{Al}\left(\mathrm{DMSO}_{2}\right)_{3}^{3+}$ and $\mathrm{AlCl}_{4}^{-}$by the reaction of Eq. (1).

$4 \mathrm{AlCl}_{3}+3 \mathrm{DMSO}_{2} \rightarrow \mathrm{Al}\left(\mathrm{DMSO}_{2}\right)_{3}^{3+}+3 \mathrm{AlCl}_{4}^{-}$

$\mathrm{AlCl}_{4}^{-}$is stable in $\mathrm{DMSO}_{2}$ bath and cannot be reduced directly to metal Al. Meanwhile, $\mathrm{Al}\left(\mathrm{DMSO}_{2}\right)_{3}^{3+}$ has a weaker binding force between metal and ligand than $\mathrm{AlCl}_{4}{ }^{-}$, and it is thought to be the source of the electrodeposited Al. In other words, Al electrodeposition can be written according to Eq. (2).

$$
\mathrm{Al}\left(\mathrm{DMSO}_{2}\right)_{3}^{3+}+3 e^{-} \rightarrow \mathrm{Al}+3 \mathrm{DMSO}_{2}
$$

When using the $\mathrm{DMSO}_{2}$ bath, it is important to control its $C_{m}$ for Al electrolysis. Moisture contamination has been reported to cause reduced current efficiency, rougher surface of the electrodeposit, and increased burn area [44]. However, the detailed relationship between water concentration in the bath and its influence has not been clarified. Clarifying this relationship is important for quality control of the electrodeposited Al film.

To answer this question, in this study electrodeposition was carried out in $\mathrm{DMSO}_{2}$ bath with intentionally added moisture, and the appearance and microstructure of the deposit and the current efficiency were analyzed. In addition, for a bath that was dried under an inert atmosphere, the change of its moisture level over time was monitored for $72 \mathrm{~h}$. Changes in the amounts of $\mathrm{Al}\left(\mathrm{DMSO}_{2}\right)_{3}^{3+}$ and $\mathrm{AlCl}_{4}^{-}$species in the $\mathrm{DMSO}_{2}$ baths were also evaluated by ${ }^{27} \mathrm{Al}$ NMR spectra.

\section{Experimentals}

\subsection{Bath preparation and electrochemical measurements}

Preparation of the electrolytic baths and electrochemical experiments were carried out in an argon-filled glove box (Cosmo, GBTV-065) that was equipped with a circulation system (Sinkukiko, GLD-200). A purifier was used to make the atmosphere in the glove box up to 1 PPM. (Operation under moisture/oxygen concentration 1 PPM in an inert gas atmosphere).

\section{SN Applied Sciences}

The electrolytic baths were prepared by stepwise addition of anhydrous $\mathrm{AlCl}_{3}$ grains (Nacalai, crystallized, 99 mass\%) into $\mathrm{DMSO}_{2}$ (Tokyo Chemical Industry, 99 mass\%). After pretreatment, the $\mathrm{DMSO}_{2}$ powder was heated in a $100-\mathrm{cm}^{3}$ glass beaker at $403 \mathrm{~K}$ to remove water by holding the powder at $333 \mathrm{~K}$ for at least $48 \mathrm{~h}$ in vacuum. Dimethyl sulfoxide ( $\left(\mathrm{CH}_{3}\right)_{2} \mathrm{SO}$, DMSO, Nacalai, 98 mass\%) and dimethyl sulfide (( $\left.\mathrm{CH}_{3}\right)_{2} \mathrm{~S}$, DMS, Nacalai, 98 mass\%) were also used to confirm that $\mathrm{DMSO}_{2}$ stably existed without decomposition in the $\mathrm{AlCl}_{3}-\mathrm{DMSO}_{2}$ bath.

Electrochemical properties were measured in the Arfilled glove box with a potentiostat/galvanostat (BioLogic, SP 150). Cyclic voltammetry (CV) was carried out using a Pt electrode and Pt coil as the working and counter electrodes, respectively, between $-2 \mathrm{~V}$ and $2 \mathrm{~V}$ versus $\mathrm{Al} / \mathrm{Al}^{3+}$ at a scan rate of $100 \mathrm{mV} \mathrm{s}^{-1}$. An Al wire directly soaked in the electrolytic bath was used as the reference electrode. The temperature was maintained at $403 \mathrm{~K}$ using a hotplate. Galvanostatic electrodeposition was performed at a current density of $40 \mathrm{~mA} \mathrm{~cm}{ }^{-2}$ on a Cu plate, which was previously polished with $\mathrm{SiC}$ paper and then cleaned by sonication in ethanol.

A part of the plate was covered with Nitoflon insulating tape so that only an area of $1 \mathrm{~cm}^{2}$ was exposed. During the electrodeposition process, the bath was agitated with a stirrer (As-one, FLHS-A-PRO) at $150 \mathrm{rpm}$. The distance between the Cu plate and the Al counter electrode was c.a. $14 \mathrm{~mm}$.

\subsection{Bath characterization}

${ }^{27} \mathrm{Al}$ NMR spectra were measured at $130.3 \mathrm{MHz}$ using a 500 NMR spectrometer (Agilent Technology). All chemical shifts were referenced to $\mathrm{D}_{2} \mathrm{O}$ containing $1.5 \mathrm{M} \mathrm{Al}\left(\mathrm{NO}_{3}\right)_{3}$ as an external reference. Samples were placed in $10 \mathrm{~mm}$ NMR tubes with a $5-\mathrm{mm}$ coaxial tube filled with DMSO- $d_{6}$ as a lock solvent. The temperature of $\mathrm{DMSO}_{2}$ was kept at $403 \mathrm{~K}$, the same as in the electrochemical measurements.

$0.2 \mathrm{~mL}$ (about $0.26 \mathrm{~g}$ ) was taken from a $\mathrm{AlCl}_{3}-\mathrm{DMSO}_{2}$ bath immediately before electrodeposition with a syringe and charged into the Karl Fischer moisture meter, whereby the $C_{m}$ in the $\mathrm{AlCl}_{3}-\mathrm{DMSO}_{2}$ bath was measured.

As will be described later, the $C_{m}$ measured by the Karl Fischer moisture meter is the total concentration of $\mathrm{H}_{2} \mathrm{O}$, $\mathrm{AlOCl}_{2}{ }^{-}$, and $\mathrm{Al}(\mathrm{OH}) \mathrm{Cl}_{3}{ }^{-}$but in the present paper this value of $C_{m}$ is defined as $\mathrm{H}_{2} \mathrm{O}$ It was used as an index of concentration. In addition, the concentration of hydrogen chloride gas generated from the bath was measured using a passive deutyube (GASTECH). 


\section{3 characterization of deposits}

After electrolysis, the deposits were characterized by means of X-ray diffraction (XRD; Rigaku Ultima IV; $40 \mathrm{kV}-30 \mathrm{~mA}, 0.4^{\circ} \mathrm{min}^{-1}$ ) and field emission scanning electron microscopy (FE-SEM; NeoScope JCM-5000, JEOL), in order to check the crystal orientation and surface morphology. Before the XRD and SEM observations, the deposits were washed with $\mathrm{AlCl}_{3}-\mathrm{DMSO}_{2}$ solution and vacuum dried.

\section{Results and discussion}

\subsection{Stability of $\mathrm{DMSO}_{2}$}

When $\mathrm{DMSO}_{2}$ as a solvent is reduced, DMSO and DMS are produced as shown in Fig. 1. Therefore, in addition to the $\mathrm{AlCl}_{3}-\mathrm{DMSO}_{2}$ bath, two other baths of $\mathrm{AlCl}_{3}-\mathrm{DMSO}$ and $\mathrm{AlCl}_{3}$-DMS were prepared to confirm that $\mathrm{DMSO}_{2}$ was chemically stable in the bath, and the electrochemical behavior was conducted.

DMSO has a high dielectric constant ( $\varepsilon=47$ ), it is difficult to oxidize and reduce, and so its potential window is wide for an organic solvent. At $403 \mathrm{~K}$, when $\mathrm{AlCl}_{3}$ is dissolved in DMSO, the bath solidified. The photograph and XRD measurement result of the coagulum are shown in Fig. 2. The XRD data confirmed that it was mainly $\mathrm{Al}_{2} \mathrm{O}_{3}$ together with some<smiles>[R5]S(C)(=O)=O</smiles>

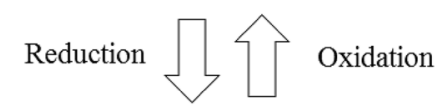

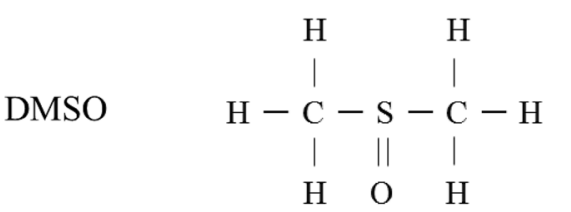

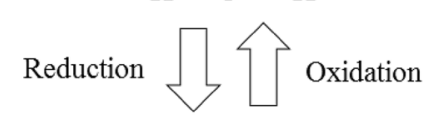

DMS

$$
\begin{array}{cc}
\mathrm{H} & \mathrm{H} \\
\mathrm{H}-\mathrm{C}-\mathrm{S} & -\mathrm{C}-\mathrm{H} \\
\mathrm{H} & \mathrm{H}
\end{array}
$$

(a)

$100 \mathrm{~mL}$ beaker

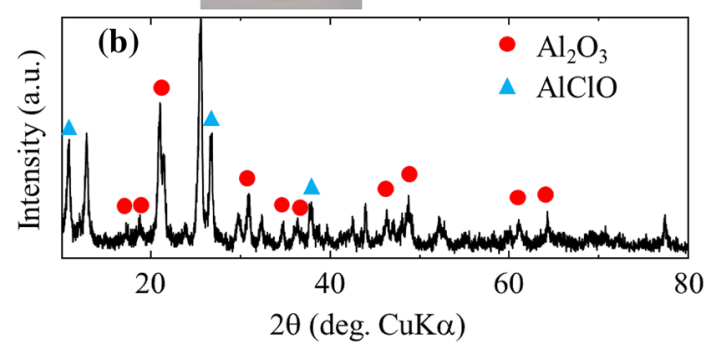

Fig. 2 Photograph of an $\mathrm{AlCl}_{3}$-DMSO coagulum (a) and XRD analysis (b)

$\mathrm{AIClO}$. It is considered that $\mathrm{DMSO}$ and $\mathrm{AlCl}_{3}$ undergo chemical reactions as shown in Eqs. (3) and (4).

$2 \mathrm{AlCl}_{3}+3 \mathrm{DMSO} \rightarrow \mathrm{Al}_{2} \mathrm{O}_{3}+3 \mathrm{DMSCl}_{2}$

$\mathrm{AlCl}_{3}+\mathrm{DMSO} \rightarrow \mathrm{AlClO}+\mathrm{DMSCl}_{2}$

Since DMSO reacted with $\mathrm{AlCl}_{3}$ to produce solidified $\mathrm{Al}_{2} \mathrm{O}_{3}$, electrochemical measurements could not be made. Therefore, $\mathrm{Al}$ electrodeposition cannot be performed in the $\mathrm{AlCl}_{3}-\mathrm{DMSO}$ bath. Meanwhile, the $\mathrm{AlCl}_{3}-\mathrm{DMSO}_{2}$ bath maintained a liquid state at $403 \mathrm{~K}$, and $\mathrm{Al}$ precipitation is obtained by galvanostatic deposition. In other words, in the $\mathrm{AlCl}_{3}-\mathrm{DMSO}_{2}$ bath, there seemed to be no conversion of $\mathrm{DMSO}_{2}$ to DMSO.

When $\mathrm{DMSO}_{2}$ is reduced and loses both of its two oxygen atoms, it becomes DMS (Fig. 1). The electrochemical behavior was also examined using $\mathrm{AlCl}_{3}$-DMS bath at $293 \mathrm{~K}$, since the boiling point of DMS is $310.3 \mathrm{~K}$. When $\mathrm{AlCl}_{3}$ particles were dissolved in the DMS bath at room temperature, the heat of dissolution caused the solution to boil. Therefore, a separable flask filled with $\mathrm{AlCl}_{3}$-DMS bath was kept at $293 \mathrm{~K}$ by using a water bath. A pseudo reference electrode with $\mathrm{Al}$ wire inserted was used in the bath. CV measurement was carried out in the $23.3 \mathrm{~mol} \% \mathrm{AlCl}_{3}-\mathrm{DMS}$ bath, and the resulting voltammogram is shown in Fig. 3. A rise in the anodic and cathodic currents was observed at around $0.8 \mathrm{~V}$. A galvanostatic electrodeposition experiment was carried out for $1 \mathrm{~h}$ at $40 \mathrm{~mA} \mathrm{~cm}^{-2}$ and $293 \mathrm{~K}$. However, no Al precipitation was observed according to XRD measurement of the cathode surface afterwards. Therefore, in the $\mathrm{AlCl}_{3}-\mathrm{DMSO}_{2}$ bath, $\mathrm{DMSO}_{2}$ is not converted to DMS (i.e., it is considered to exist stably).

Fig. 1 Redox reactions of dimethylsulfone 


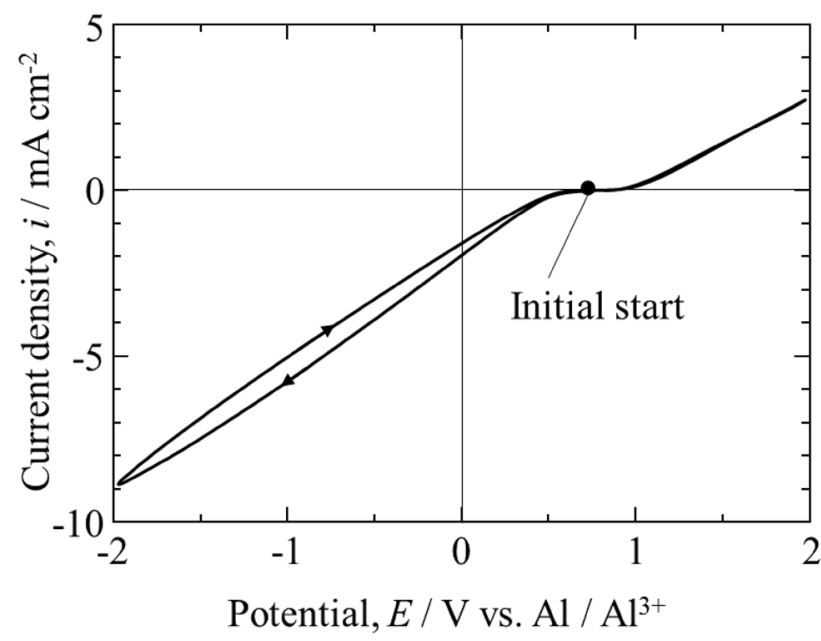

Fig. 3 Cyclic voltammograms of Pt electrode in $23.3 \mathrm{~mol} \% \mathrm{AlCl}_{3}-$ DMS baths at $293 \mathrm{~K}$

\subsection{Effect of moisture in the bath}

The CV measurements were performed using two baths adjusted to different $C_{m}$ in order to clarify the influence of moisture on $\mathrm{Al}$ reactions in $\mathrm{AlCl}_{3}-\mathrm{DMSO}_{2}$. A bath of $23.3 \mathrm{~mol} \% \mathrm{AlCl}_{3}-\mathrm{DMSO}_{2}(80 \mathrm{~mL})$ at $403 \mathrm{~K}$ was prepared and designated as bath (a). Another bath (b) was prepared by dropping $100 \mu \mathrm{L}(0.13 \mathrm{vol} \%)$ of distilled water into bath (a). The $C_{m}$ of the dried $\mathrm{DMSO}_{2}$ was measured to be $9 \mathrm{ppm}$, and that of the bath prepared by dissolving $\mathrm{AICl}_{3}$ in this $\mathrm{DMSO}_{2}$ (i.e. bath (a)) was $67 \mathrm{ppm}$. After adding distilled water, the moisture was $390 \mathrm{ppm}$ in bath (b).

$\mathrm{CV}$ experiments were carried out in the potential range from -2 to $2 \mathrm{~V}$ in $23.3 \mathrm{~mol} \% \mathrm{AlCl}_{3}-\mathrm{DMSO}_{2}$ baths at $403 \mathrm{~K}$. Figure 4 shows the cyclic voltammograms recorded after

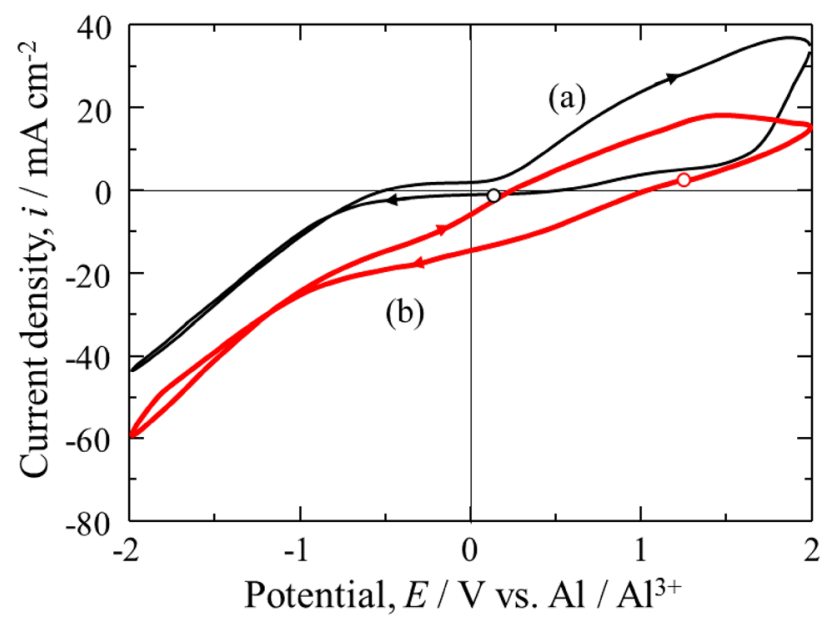

Fig. 4 Cyclic voltammograms of Pt electrode in $23.3 \mathrm{~mol} \% \mathrm{AlCl}_{3}-$ $\mathrm{DMSO}_{2}$ baths at $403 \mathrm{~K}$. a 67 ppm $\mathrm{H}_{2} \mathrm{O}$, b 390 ppm $\mathrm{H}_{2} \mathrm{O}$
20 cycles. The shapes of the curves did not change after three cycles. It is clear that the moisture affects the CV behavior.

The open circuit potential at the beginning of the CV scan is $0.2 \mathrm{~V}$ in bath (a) and $1.2 \mathrm{~V}$ in bath (b). The main electrochemical reaction in bath (a) is Al deposition, cathodic current, and $\mathrm{Al}$ dissolution, anodic current, changing in around $0.2 \mathrm{~V}$. On the other hand, in bath (b) the redox reaction of water becomes dominant. It is considered that a large amount of $\mathrm{H}^{+}$ions is reduced to hydrogen gas, corresponding to the cathodic current below $1.0 \mathrm{~V}$ as shown in Eq. (5).

$2 \mathrm{H}^{+}+2 \mathrm{e} \rightarrow \mathrm{H}_{2}$

This cathodic current of hydrogen evolution accompanied with Al deposition leads to a high current of $60 \mathrm{~mA} \mathrm{~cm}^{-2}$ in bath (b), in comparison to the value of $48 \mathrm{~mA} \mathrm{~cm}^{-2}$ in bath (a) observed at $-2 \mathrm{~V}$. The anodic current corresponding to $\mathrm{Al}$ dissolution also decreases with increased water content in the bath.

After CV measurement, the galvanostatic electrodepositions were carried out for $1 \mathrm{~h}$ at $40 \mathrm{~mA} \mathrm{~cm}^{-2}$ and $403 \mathrm{~K}$. Figure 5 shows photographs of the surface of Al film obtained in bath (a) and bath (b). When moisture was added in the bath, the Al surface was blackened and became much thinner. The thickness of Al film is $45 \mu \mathrm{m}$ in bath (a) and $10 \mu \mathrm{m}$ in bath (b), as measured from cross-sectional SEM observation, and the current efficiencies were $90 \%$ and $19 \%$, respectively.

(a)
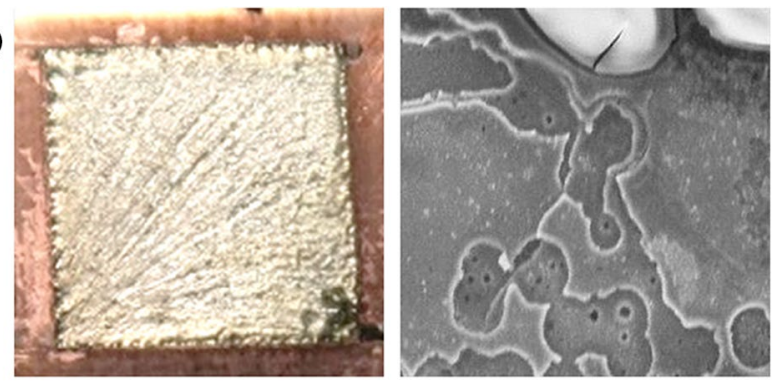

(b)
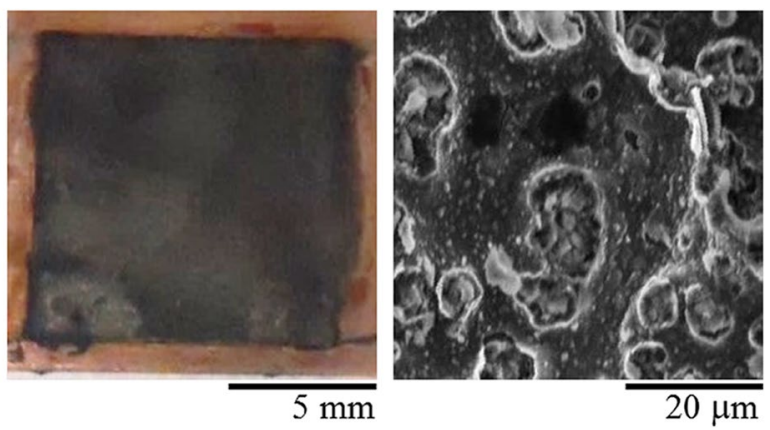

Fig. 5 Surface photographs and SEM images of Al electrodeposited on $\mathrm{Cu}$ substrate under $40 \mathrm{mAcm}^{-2}$ for $1 \mathrm{~h}$ in $23.3 \mathrm{~mol} \% \mathrm{AlCl}_{3}-$

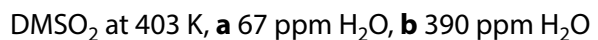


Considering the electrolysis at $40 \mathrm{~mA} \mathrm{~cm}^{-2}$ for $1 \mathrm{~h}$, i.e., $144 \mathrm{C}_{2} \mathrm{O}$ decomposition to hydrogen gas corresponds to $117 \mathrm{C}, 81 \%$ current efficiency of $144 \mathrm{C}$. This consumes $(144 \times 0.81) / 96500=1.21 \mathrm{mmol}_{2} \mathrm{O}$ from bath (b) containing $5.56 \mathrm{mmol} \mathrm{H}_{2} \mathrm{O}$. Therefore, it is considered that the remaining $81 \%$ current was all consumed for hydrogen generation.

In addition, the influence of moisture on ionic species in the bath and on the electrodeposition of Al was estimated by NMR spectroscopy, since ${ }^{27}$ AI NMR spectroscopy allows unambiguous determination of the environment of $\mathrm{Al}$ atoms in most cases. In the literature, several regions of the NMR spectrum have been already assigned to Al species in different environments. For example, octahedral Al can be found at chemical shifts of around 0 ppm in the ${ }^{27} \mathrm{Al}$ NMR spectra, while tetrahedral Al can be found at around 100 ppm $[45,46]$.

The ${ }^{27}$ Al NMR spectra obtained for the two electrolytes are shown in Fig. 6. $\mathrm{AlCl}_{4}^{-}$and $\mathrm{Al}\left(\mathrm{DMSO}_{2}\right)_{3}^{3+}$ species were formed in $\mathrm{AlCl}_{3}-\mathrm{DMSO}_{2}$ baths at $403 \mathrm{~K}$ with both bath (a) and bath (b). The sulfone-solvated $\mathrm{Al}^{3+}$ species are generated together with $\mathrm{AlCl}_{4}{ }^{-}$[32]. Since the source of $\mathrm{Cl}^{-}$is $\mathrm{AlCl}_{3}$, asymmetric cleavage of $\mathrm{AlCl}_{3}$ forms $\mathrm{AlCl}_{4}{ }^{-}$and $\mathrm{Al}\left(\mathrm{DMSO}_{2}\right)_{3}^{3+}$. It was confirmed that the chemical shift of $\mathrm{AlCl}_{3}-\mathrm{DMSO}_{2}$ at $403 \mathrm{~K} \mathrm{included} \mathrm{signals} \mathrm{of} \mathrm{AlCl}_{4}^{-}(110 \mathrm{ppm})$ and $\mathrm{Al}\left(\mathrm{DMSO}_{2}\right)_{3}^{3+}(-10 \mathrm{ppm})$. The assignments of these chemical shifts were based on the work of Legrand et al. [32] It is known that $\mathrm{AlCl}_{4}^{-}$is electrochemically inactive, while $\mathrm{Al}_{2} \mathrm{Cl}_{7}^{-}$is active in room-temperature ionic liquids. Since the anionic species in baths (a) and (b) is $\mathrm{AlCl}_{4}{ }^{-}$, we conclude that the cationic species $\mathrm{Al}\left(\mathrm{DMSO}_{2}\right)_{3}^{3+}$ is electrochemically active. The NMR peak of the ionic Al complex $\mathrm{Al}\left(\mathrm{DMSO}_{2}\right)_{3}^{3+}$ became more intense when water was added to bath (b). The concentration ratio of $\mathrm{Al}\left(\mathrm{DMSO}_{2}\right)_{3}^{3+}$ is $33.7 \%$ for bath (a) and decreases to $25.5 \%$ for bath (b). This is related to the remarkable reduction in current efficiency when moisture was mixed in the $\mathrm{AlCl}_{3}-\mathrm{DMSO}_{2}$ bath.

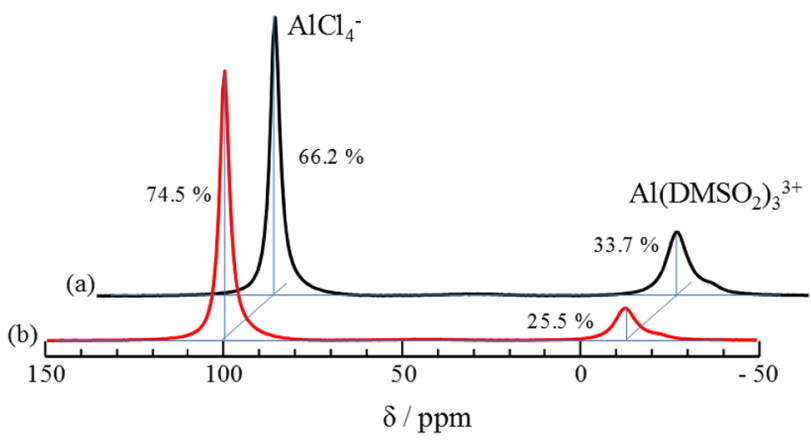

Fig. $6{ }^{27} \mathrm{Al}$ NMR spectra of $23.3 \mathrm{~mol} \% \mathrm{AlCl}_{3}-\mathrm{DMSO}_{2}$ electrolytes and involved $\mathrm{Al}$ species at $403 \mathrm{~K}$. a 67 ppm H $\mathrm{H}_{2} \mathrm{O}$, b 390 ppm $\mathrm{H}_{2} \mathrm{O}$

\subsection{Moisture change with time and influence on electrodeposition}

It was confirmed that the current efficiency was reduced and a black film was formed, when much $\mathrm{H}_{2} \mathrm{O}$ was contained in the $\mathrm{AlCl}_{3}-\mathrm{DMSO}_{2}$ bath. Therefore, it is desirable to keep the $C_{m}$ in the bath as low as possible. The experimental results mentioned above were obtained by conducting electrodeposition immediately after adding distilled water to the bath. On the other hand, in this section, the $\mathrm{AlCl}_{3}-\mathrm{DMSO}_{2}$ bath was kept at $403 \mathrm{~K}$ in an argon atmosphere, where the moisture in the bath will evaporate in time. The $C_{m}$ in the bath over time was monitored, and the results are shown in Fig. 7. Okamoto et al. [44] reported that baths with a $C_{m}$ of about $350 \mathrm{ppm}$ or more gradually dry out with the lapse of time, while those with a lower $C_{m}$ accumulate moisture to approach ca. $350 \mathrm{ppm}$. In this study, when the initial bath $C_{m}$ was $67 \mathrm{ppm}$, its value decreased to $61 \mathrm{ppm}$ after $6 \mathrm{~h}$. However, from 6 to $72 \mathrm{~h}$, the $C_{m}$ increased again.

In the molten salt or ionic liquid containing $\mathrm{AlCl}_{3}$, any $\mathrm{H}_{2} \mathrm{O}$ present will gradually react with $\mathrm{AlCl}_{4}{ }^{-}$to form $\mathrm{Al}(\mathrm{OH})$ $\mathrm{Cl}_{3}{ }^{-}$and $\mathrm{HCl}$ according to Eq. (6). It has been reported that $\mathrm{HCl}$ is released from $\mathrm{Al}(\mathrm{OH}) \mathrm{Cl}_{3}{ }^{-}$to produce $\mathrm{AlOCl}_{2}{ }^{-}$, as represented in Eq. (7) $[44,47]$.

$\mathrm{AlCl}_{4}^{-}+\mathrm{H}_{2} \mathrm{O} \rightarrow \mathrm{Al}(\mathrm{OH}) \mathrm{Cl}_{3}^{-}+\mathrm{HCl}$

$\mathrm{Al}(\mathrm{OH}) \mathrm{Cl}_{3}^{-} \rightarrow \mathrm{AlOCl}_{2}^{-}+\mathrm{HCl}$

Hence, it is considered that chemical species of $\mathrm{Al}(\mathrm{OH})$ $\mathrm{Cl}_{3}{ }^{-}, \mathrm{AlOCl}_{2}{ }^{-}$, and $\mathrm{HCl}$ are formed in the bath when $\mathrm{H}_{2} \mathrm{O}$ is present. The $C_{m}$ in the bath was measured by the Karl

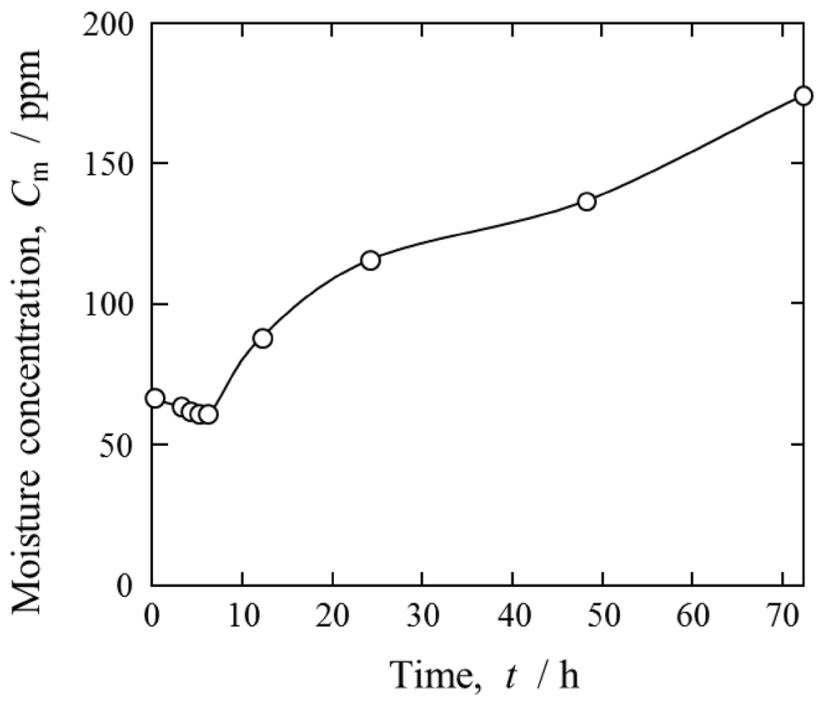

Fig. 7 Change in moisture content of $\mathrm{DMSO}_{2}$ baths retained at $403 \mathrm{~K}$ in a glove box 
Fischer Coulometric titration method in this experiment, utilizing the selective and quantitative reaction between water in the sample and iodine in the Karl Fischer reagent. However, when $\mathrm{Al}(\mathrm{OH}) \mathrm{Cl}_{3}{ }^{-}$or $\mathrm{AlOCl}_{2}{ }^{-}$is present in the sample, these ions react with components other than iodine in the Karl Fischer reagent to release $\mathrm{H}_{2} \mathrm{O}$ in the same amount as $\mathrm{Al}(\mathrm{OH}) \mathrm{Cl}_{3}^{-}$or $\mathrm{AlOCl}_{2}^{-}$. [44].

Chemical species other than $\mathrm{AlOCl}_{2}{ }^{-}$among $\mathrm{H}_{2} \mathrm{O}, \mathrm{Al}(\mathrm{OH})$ $\mathrm{Cl}_{3}{ }^{-}, \mathrm{AlOCl}_{2}{ }^{-}$and $\mathrm{HCl}$ which are chemical species derived from water have protons, this proton Is reduced to $\mathrm{H}_{2}$ gas may occur as a side reaction on the cathode at the time of Al electrodeposition. On the other hand, $\mathrm{AlOCl}_{2}{ }^{-}$has no possibility of being reduced in addition to being reduced to metal Al. $\mathrm{AlOCl}_{2}{ }^{-}$is a chemical species derived from $\mathrm{H}_{2} \mathrm{O}$, the amount of which is included in a part of the $C_{m}$ measured by the Karl Fischer moisture meter. However, since $\mathrm{AlOCl}_{2}^{-}$has no possibility of being reduced only to metal Al, it does not contribute to reduction in current efficiency. Although the formation rate of $\mathrm{AlOCl}_{2}{ }^{-}$is slow, it is thought that a sufficient amount of $\mathrm{AlOCl}_{2}{ }^{-}$is produced when the bath is heated and kept for $24 \mathrm{~h}$ or more. (The measurement of the current efficiency is shown in Fig. 10).

The reason why the $C_{m}$ of the bath rose after $6 \mathrm{~h}$ in Fig. 7 is that the $\mathrm{AlOCl}_{2}^{-}$produced by the reaction with water in the argon atmosphere was measured by the Karl Fischer moisture meter.

To investigate how the gradual drying of the $\mathrm{AlCl}_{3}-\mathrm{DMSO}_{2}$ bath affects $\mathrm{Al}$ electrodeposition in it, CV experiments were carried out in the potential range from -2 to $2 \mathrm{~V}$ for baths that had been dried for $0-72 \mathrm{~h}$ at $403 \mathrm{~K}$ in a glove box. The voltammograms recorded after 20 time cycles are shown in Fig. 8. The shape of the curves did not change after three cycles. The electrode potential was scanned from the open-circuit potential near $0 \mathrm{~V}$ in the negative direction, followed by scanning in the positive direction and then cycling. In each curve, the anodic current increased at approximately $0.2 \mathrm{~V}$ while the cathodic current decreased at $-0.6 \mathrm{~V}$. Therefore, the overvoltage for $A l$ redox reaction in the anodic and cathodic reactions was 0.1 and $0.4 \mathrm{~V}$, respectively, and so the dried solution slightly influenced the Al electrodeposition process. After drying for $72 \mathrm{~h}$, when the bath reached the highest $C_{m}$, the current density required for $\mathrm{Al}$ deposition and dissolution was the smallest. In contrast, these current densities were the largest after drying the bath for 5-6 $\mathrm{h}$.

In addition, to estimate the effect of ions in the bath on the deposit component, NMR spectra was recorded for all electrolytic $\mathrm{AlCl}_{3}-\mathrm{DMSO}_{2}$ baths after they were kept at $403 \mathrm{~K}$ in glove box for 0 to $72 \mathrm{~h}$ (Fig. 9). The results clarified that $\mathrm{AlCl}_{4}^{-}$and $\mathrm{Al}\left(\mathrm{DMSO}_{2}\right)_{3}^{3+}$ existed in the baths, while $\mathrm{Al}_{2} \mathrm{Cl}_{7}^{-}$was never observed. A peak corresponding to $\mathrm{AlCl}_{4}^{-}$was detected in the vicinity of $104 \mathrm{ppm}$ in all baths [32]. The peak of $\mathrm{Al}\left(\mathrm{DMSO}_{2}\right)_{3}^{3+}$ appeared between

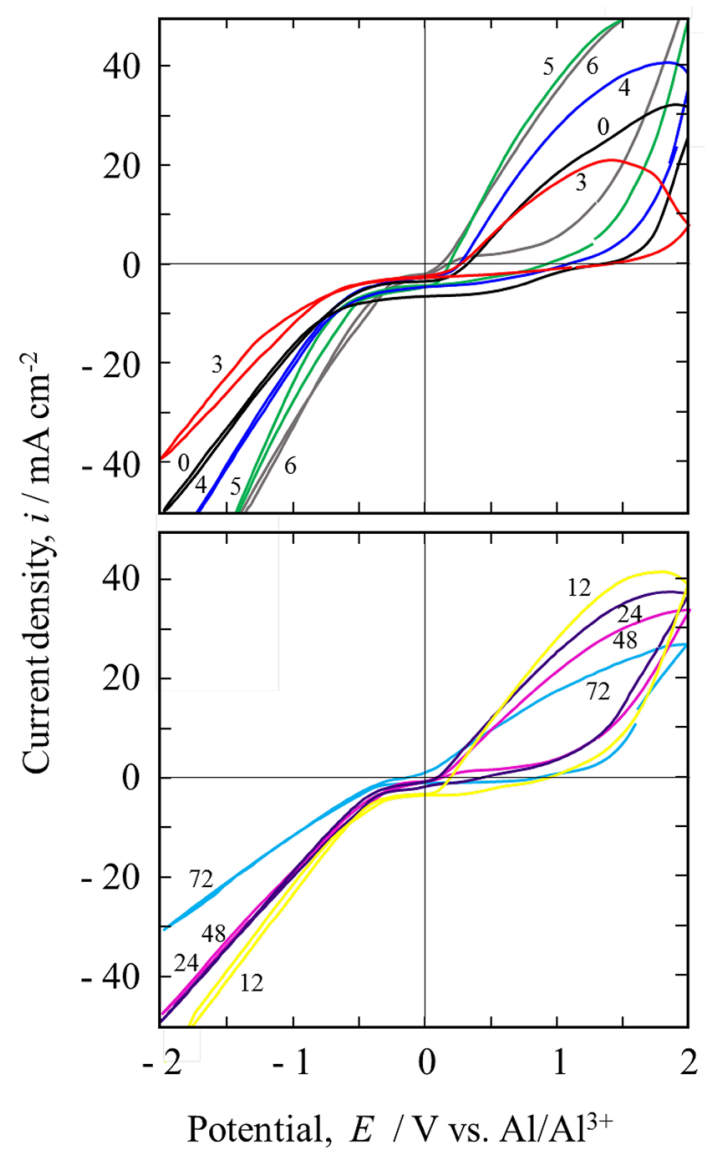

Fig. 8 Effect of time on cyclic voltammograms of Pt electrode in $23.3 \mathrm{~mol} \% \mathrm{AlCl}_{3}-\mathrm{DMSO}_{2}$ baths at $403 \mathrm{~K}$ in glove box. Number denotes time in hour

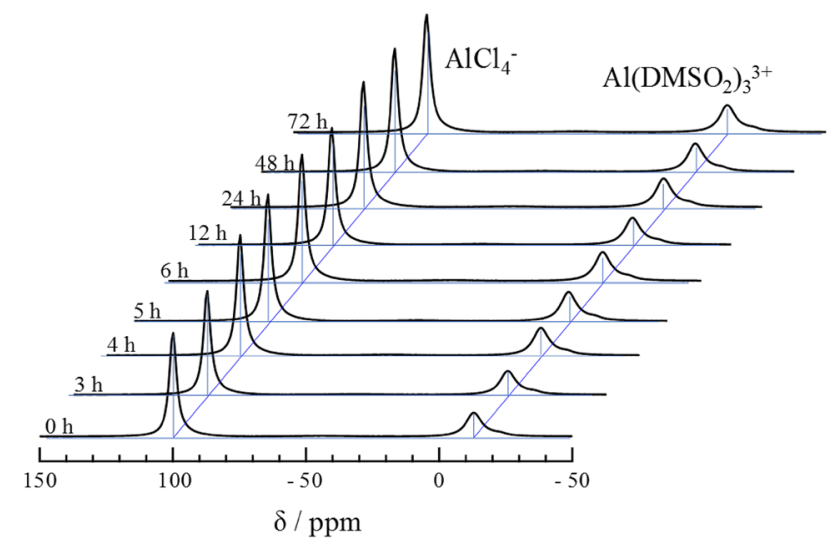

Fig. $9{ }^{27} \mathrm{Al}$ NMR spectra of $23.3 \mathrm{~mol} \% \mathrm{AlCl}_{3}-\mathrm{DMSO}_{2}$ baths with time at $403 \mathrm{~K}$ in glove box

$-10 \mathrm{ppm}$. For $\mathrm{Al}\left(\mathrm{DMSO}_{2}\right)_{3}^{3+}$, which is an $\mathrm{Al}$ complex ion, its peak is obvious until the drying time of $6 \mathrm{~h}$. However, after $6 \mathrm{~h}$, this peak becomes weaker and difficult to observe in the spectra, so the proportion of ion species was 


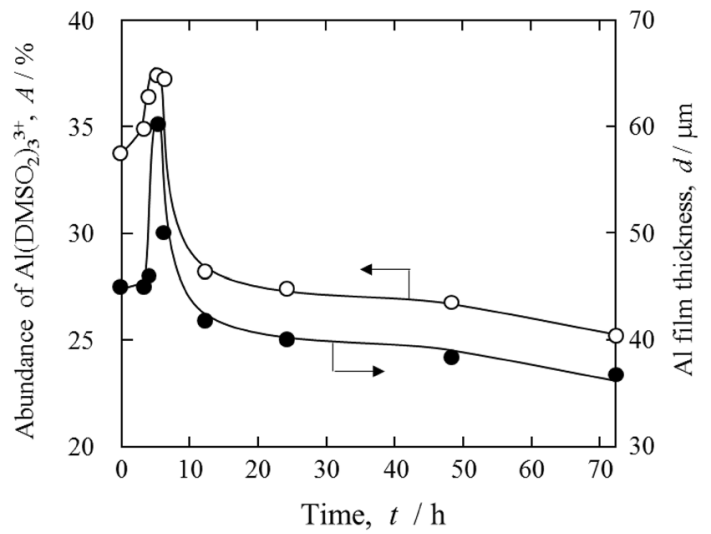

Fig. 10 Abundance of $\mathrm{Al}\left(\mathrm{DMSO}_{2}\right)_{3}^{3+}$ to $\mathrm{AlCl}_{4}^{-}$from NMR spectra of $23.3 \mathrm{~mol} \% \mathrm{AlCl}_{3}-\mathrm{DMSO}_{2}$ baths with time at $403 \mathrm{~K}$ in glove box and Al film thickness electrodeposited at $40 \mathrm{mAcm}^{-2}$ for $1 \mathrm{~h}$

investigated. Figure 10 shows the relative abundance of $\mathrm{Al}\left(\mathrm{DMSO}_{2}\right)_{3}^{3+}$ to $\mathrm{AlCl}_{4}{ }^{-}$and the $\mathrm{Al}$ film thickness measured from cross-sectional SEM images at each drying time. The current efficiency was calculated from the amount of current flow and the film thickness. After the bath was dried for $5 \mathrm{~h}$, the current efficiency (Calculated from film thickness) was as high as $120 \%$, whereas it was significantly reduced to $74 \%$ after $72 \mathrm{~h}$.

In some cases, the contributions of underlying NMR peaks could be estimated by deconvolution of peak shoulders. The ratios from the integrated areas under the assigned peaks were compared to those measured by titration, in order to cross-check the composition. The concentration of $\mathrm{Al}\left(\mathrm{DMSO}_{2}\right)_{3}^{3+}$ increased with drying time until $5 \mathrm{~h}$, and remained almost unchanged afterwards.

When combined with the observation that $\mathrm{AlCl}_{4}{ }^{-}$concentration increases with drying time, this finding indicates that the decreased current observed after $12 \mathrm{~h}$ results from a lower $\mathrm{Al}\left(\mathrm{DMSO}_{2}\right)_{3}^{3+}$ concentration, which leads to reduced $\mathrm{Al}$ electrodeposition. Furthermore, increased viscosity of the bath may compromise the deposition. The results show that electrodeposition of $\mathrm{Al}$ is optimal in the $\mathrm{AlCl}_{3}-\mathrm{DMSO}_{2}$ bath that had been dried for 5-6 h.

The galvanostatic electrodepositions were carried out at a current density of $40 \mathrm{~mA} \mathrm{~cm}{ }^{-2}$ for $1 \mathrm{~h}$ at $403 \mathrm{~K}$. The surface and cross-sectional SEM images can be seen in Figs. 11 and 12.

At $\mathrm{O} \mathrm{h}$ (without drying), significant cracking is found on the surface of the Al film, and the cross-section Al layer is approximately $45 \mu \mathrm{m}$ in thickness with cracks inside, which may have contributed to its poor appearance. In the samples that had been dried for 5 and $6 \mathrm{~h}$, a small number of cracks can be seen even though some regions appear entirely clear. After drying for more than $12 \mathrm{~h}$, an Al film was formed, but a small amount of $\mathrm{DMSO}_{2}$ and some cracks were found to have formed.

The XRD profiles for the deposits, shown in Fig. 13, confirmed that the deposits consisted of crystalline $\mathrm{Al}$ metal without trace impurities such as $\mathrm{Al}_{2} \mathrm{O}_{3}$. Here, the intensities were normalized to the height of the (200) peak of Cu substrate at $51^{\circ}$.

In each of these patterns, diffraction peaks related to Al (111), (200), (220), and (311) were observed. The Al (200) reflection was notably high compared to $\mathrm{Al}$ (111), indicating that the preferential orientation of the $\mathrm{Al}$ deposit changed from (111) to (200). Also, the intensity of Al (200) diffraction peak increases for samples electrodeposited from baths with low $C_{m}$. So, the presence of moisture in the bath probably affected the crystal orientation of the electrodeposited Al. After drying the $\mathrm{AlCl}_{3}-\mathrm{DMSO}_{2}$ bath with moisture for $6 \mathrm{~h}$ in the argonfilled glove box, the current efficiency of Al electrolysis was improved, and a smooth Al electrodeposition film can be obtained.

Since the $C_{m}$ in the Al electrodepositions decreased by the drying baths, the hardness of the Al electrodepositions was expected to decrease. Figure 14 shows the Vickers hardness values of Al electrodeposits obtained after drying the bath for different amounts of time. For the bath without drying, the Al films had a hardness of $1.50 \mathrm{GPa}$, while that with low moisture contents exhibited a low hardness of $0.27 \mathrm{GPa}$.

In $\mathrm{Al}$ electrodeposition from an $\mathrm{AlCl}_{3}-\mathrm{DMSO}_{2}$ bath, sulfur and chlorine derived from the bath are contained in the electrodeposition film as impurities [35]. In order to investigate the effect caused by the increase in $C_{m}$, the impurity concentration in the electrodeposited Al film was measured using EDX as shown in Fig. 15.

Sulfur and chlorine were contained in the electrodeposition film obtained from the bath with the drying for $5 \mathrm{~h}$ respectively at 1.10 and 0.95 mass $\%$. These impurity concentrations increased with the increase in the $C_{m}$ in the bath and chlorine and sulfur concentrations of the electrodeposited film obtained from the bath with the drying for $72 \mathrm{~h}$ were 2.57 and 1.97 mass\%, respectively.

The impurity incorporation occurs by depositing Al atoms on impurity ions or molecules adsorbed on the surface of the Al deposit [48]. In the present case, the incorporation rate is thought to be limited by the slow adsorption of the impurity ions from the electrolyte onto the $\mathrm{Al}$ deposit. Since $\mathrm{Cl}$ is present in the electrolyte as negatively charged $\mathrm{AlCl}_{4}{ }^{-}$ions, its adsorption rate onto the cathode surface must be small and further decrease as the cathode potential becomes more negative. Therefore, the hypothesis can be made that the adsorption rate of $\mathrm{AlCl}_{4}^{-}$onto the cathode surface limits the incorporation of $\mathrm{Cl}$ into the Al coating. 

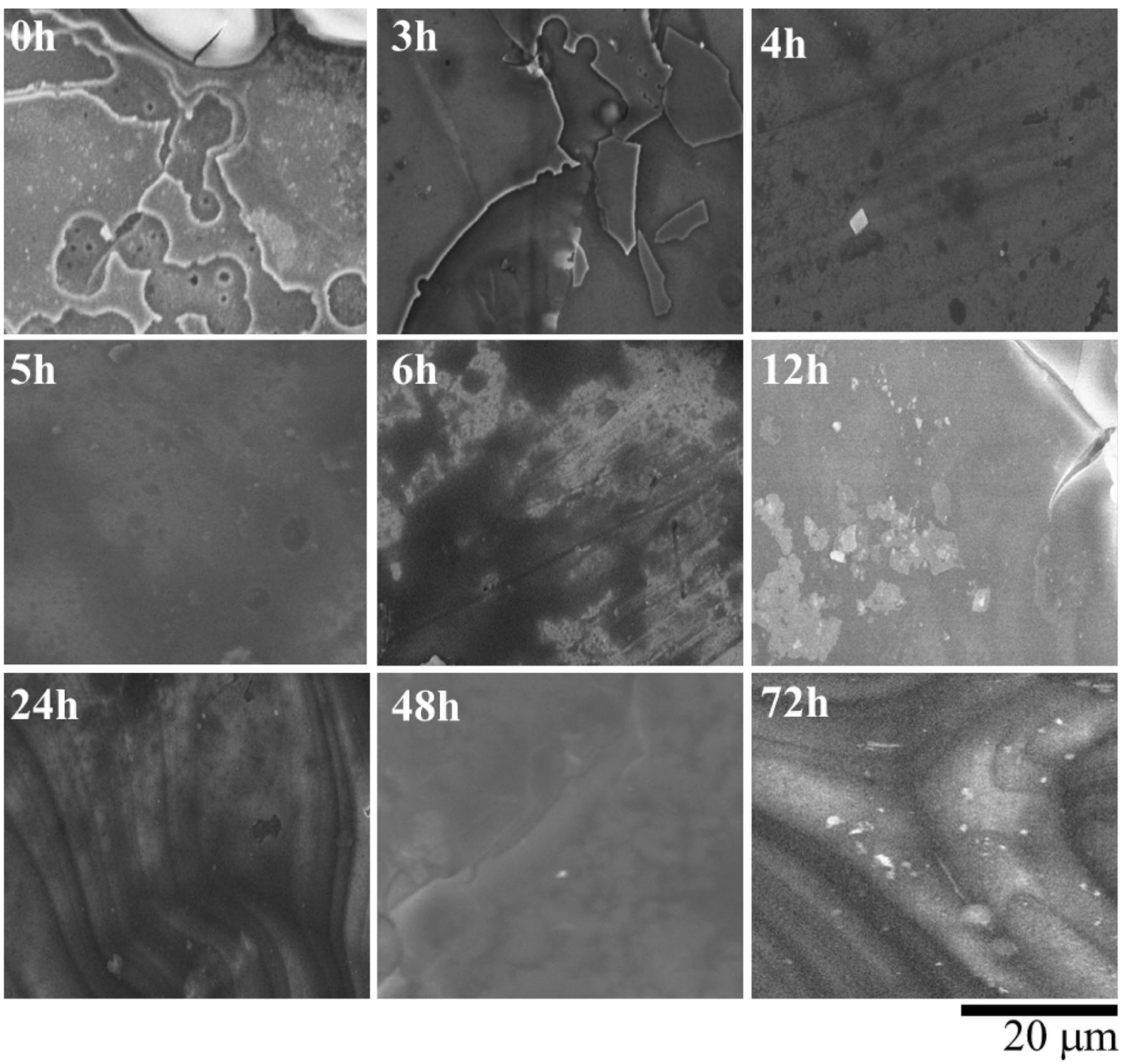

Fig. 11 Change in SEM images of Al films electrodeposited on Cu substrate under $40 \mathrm{mAcm}^{-2}$ for $1 \mathrm{~h}$ in $23.3 \mathrm{~mol}^{2} \mathrm{AlCl}_{3}-\mathrm{DMSO}_{2}$ at $403 \mathrm{~K}$ with time retained in glove box

As the $C_{m}$ of the bath increases, the concentration of impurities incorporated into the electrodeposited Al film increases. The contamination of impurities in the electrodeposition film in this system is due to the fact that during electrodeposition, ions or molecules containing sulfur and chlorine present in the bath adsorb to the surface of the Al electrodeposition film and Al is further electrodeposited thereon It is believed to happen. Therefore, when the current density during electrodeposition is lowered, the concentration of impurities incorporated in the electrodeposition film increases because the deposition rate of impurities remains unchanged while the electrodeposition rate of Al decreases. In other words, the rate at which impurities adsorb onto the electrodeposited film is not affected by the water concentration in the bath and is considered to be almost constant. Therefore, it is considered that the impurity concentration in the electrodeposited film increased with an increase in $C_{m}$.

Although the hardness of metallic materials generally depends on the crystal grain size, there was no correlation between the morphology and the hardness of the Al electrodepositions in the present case; The lowest hardness obtained in this study was only slightly higher than that for pure $\mathrm{Al}(0.23-0.29 \mathrm{GPa})$, as reported in the literature $[49,50]$.

\section{Conclusions}

In this study, the influence of $C_{m}$ on Al electrodeposition from $\mathrm{AlCl}_{3}-\mathrm{DMSO}_{2}$ bath was investigated, and the current efficiency and the appearance/fine structure of the

\section{SN Applied Sciences}



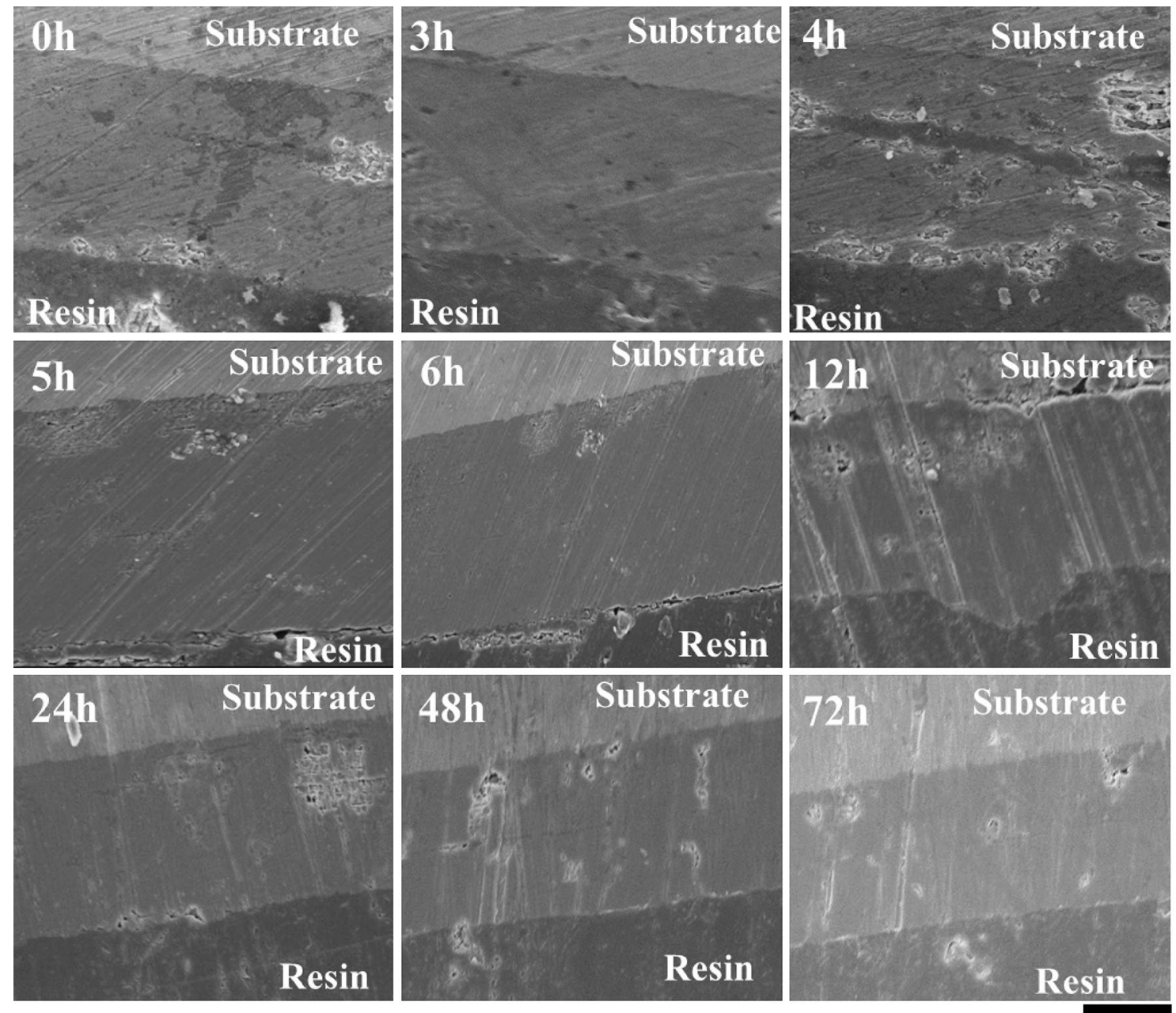

$20 \mu \mathrm{m}$

Fig. 12 Change in SEM images of cross-section of Al films electrodeposited on Cu substrate under $40 \mathrm{mAcm}^{-2}$ for $1 \mathrm{~h}$ in $23.3 \mathrm{~mol} \% \mathrm{AlCl}_{3}-$ $\mathrm{DMSO}_{2}$ at $403 \mathrm{~K}$ with time retained in glove box

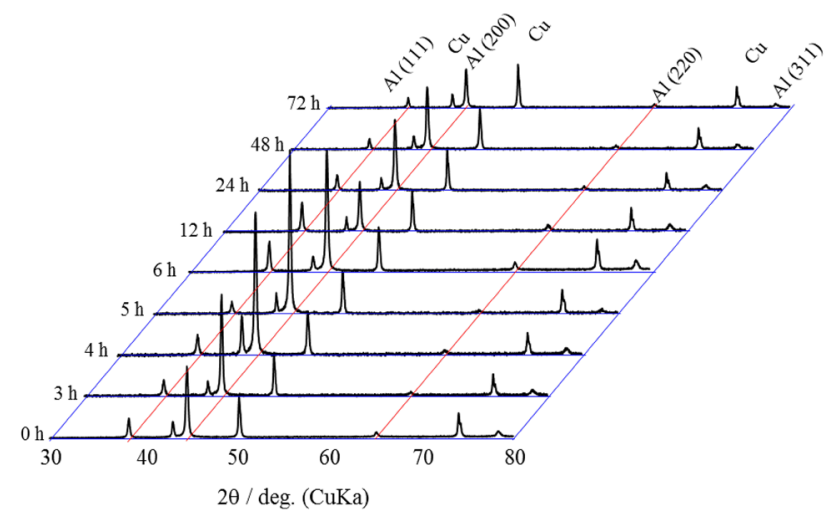

Fig. 13 XRD patterns of $\mathrm{Al}$ electrodeposited on Cu substrate under $40 \mathrm{mAcm}^{-2}$ for $1 \mathrm{~h}$ in $23.3 \mathrm{~mol} \% \mathrm{AlCl}_{3}-\mathrm{DMSO}_{2}$ bath with time at $403 \mathrm{~K}$ in glove box obtained Al film were analyzed. In addition, we measured the change of $C_{m}$ in a heated $\mathrm{AlCl}_{3}-\mathrm{DMSO}_{2}$ bath in argon atmosphere over time, as well as the corresponding effects on the $\mathrm{Al}$ electrodeposition. In the $\mathrm{AlCl}_{3}-\mathrm{DMSO}_{2}$ bath, $\mathrm{DMSO}_{2}$ was stable without decomposition into DMSO or DMS. The hydrogen generation reaction became more significant with increased water concentration, and it competed with the Al precipitation reaction. When the $\mathrm{AlCl}_{3}-\mathrm{DMSO}_{2}$ bath was heated and kept in the glove box, its moisture content as measured by the Karl Fischer moisture meter decreased with time. It was revealed that, after 5-6 h of drying the bath, the current efficiency of Al electrodeposition improved, and an electrodeposited film with uniform surface could be obtained. The likely reason is that both moisture in the bath and $\mathrm{HCl}$ produced by reaction between water and $\mathrm{AlCl}_{4}{ }^{-}$gradually evaporated under heating. Minimizing the $C_{m}$ in the bath is important 


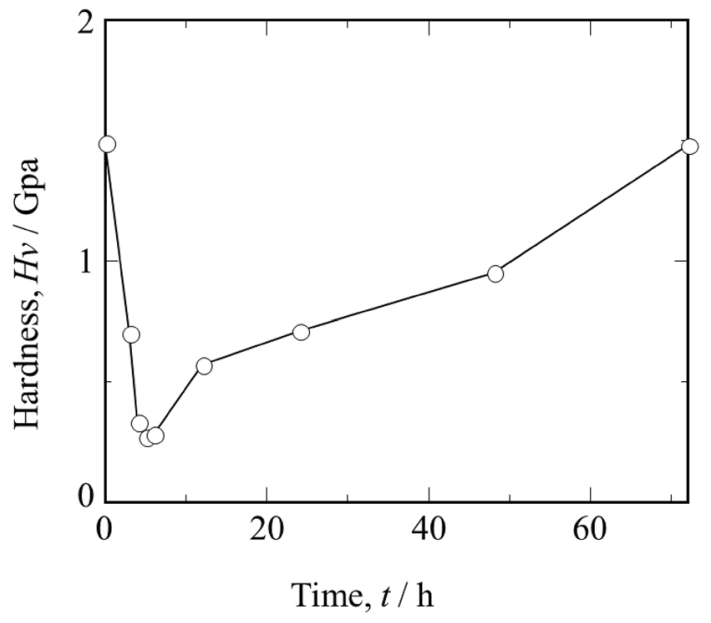

Fig. 14 Vickers hardness of Al film electrodeposited on $\mathrm{Cu}$ substrate under $40 \mathrm{mAcm}^{-2}$ for $1 \mathrm{~h}$ from $23.3 \mathrm{~mol} \% \mathrm{AlCl}_{3}-\mathrm{DMSO}_{2}$ at $403 \mathrm{~K}$ in glove box

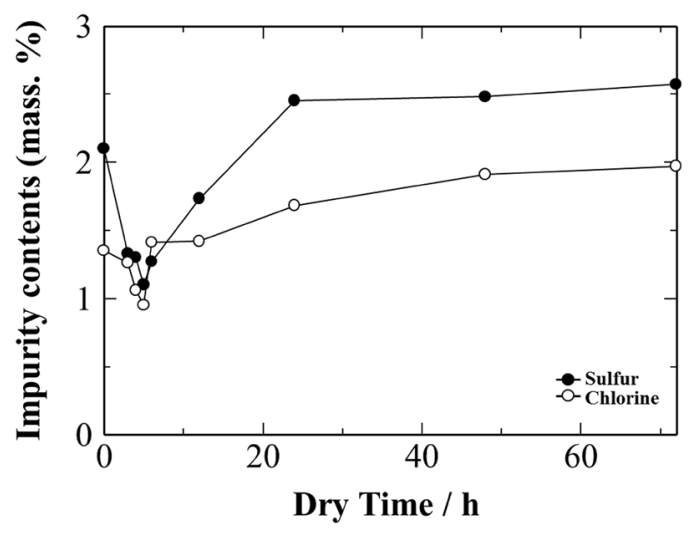

Fig. 15 Impurity (chlorine and sulfur) contents in Al film electrodeposited on $\mathrm{Cu}$ substrate under $40 \mathrm{mAcm}^{-2}$ for $1 \mathrm{~h}$ from $23.3 \mathrm{~mol} \% \mathrm{AlCl}_{3}-\mathrm{DMSO}_{2}$ at $403 \mathrm{~K}$ in glove box

for obtaining high-purity electrodeposited Al films with uniform surface at high current efficiency.

\section{Compliance with ethical standards}

Conflicts of interest The authors declare that they have no conflict of interest.

\section{References}

1. El Abedin SZ, Moustafa EM, Hempelmann R, Natter H, Endres F (2005) Additive free electrodeposition of nanocrystalline aluminium in a water and air stable ionic liquid. Electrochem Commun 7:1111

2. El Abedin SZ, Moustafa EM, Hempelmann R, Natter H, Endres $F$ (2006) Electrodeposition of nano- and microcrystalline aluminium in three different air and water stable ionic liquids. J Phys Chem 7:1535

3. Chang JK, Chen SY, Tsai WT, Deng MJ, Sun IW (2007) Electrodeposition of aluminum on magnesium alloy in aluminum chloride $\left(\mathrm{AICl}_{3}\right.$ )-1-ethyl-3-methylimidazolium chloride (EMIC) ionic liquid and its corrosion behavior. Electrochem Commun 9:1602

4. Barchi L, Bardi U, Caporali S, Fantini M, Scrivani A, Scrivani A (2010) Electroplated bright aluminium coatings for anticorrosion and decorative purposes. Prog Org Coat 67:146

5. Abbott F, Qiu H, Abood M Ali, Ryder K (2010) Double layer, diluent and anode effects upon the electrodeposition of aluminium from chloroaluminate based ionic liquids. Phys Chem Chem Phys 12:1862

6. Takahashi S, Akimoto K, Saeki I (1989) Aluminum Plating from the room temperature molten salt electrolyte. J Surf Finish Soc Jpn 40:134

7. Abbott AP, Eardley CA, Farley NRS, Griffith GA, Pratt A (2001) Electrodeposition of aluminium and aluminium/platinum alloys from $\mathrm{AlCl}_{3} /$ benzyltrimethylammonium chloride room temperature ionic liquids. J Appl Electrochem 31:1345

8. Liao Q, Pitner WR, Stewart G, Hussey CL, Stafford GR (1997) Electrodeposition of aluminum from the aluminum chloride-1-methyl-3-ethylimidazolium chloride room temperature molten salt + benzene. J Electrochem Soc 144:936

9. Hurley FH, Wier TP (1951) The electrodeposition of aluminum from nonaqueous solutions at room temperature. J Electrochem Soc 98:207-212

10. Jafarian M, Gobal F, Danaee I, Mahjani MG (2007) Impedance spectroscopy study of aluminum electrocrystallization from basic molten salt $\left(\mathrm{AlCl}_{3}-\mathrm{NaCl}-\mathrm{KCl}\right)$. Electrochim Acta 52:5437

11. Jafarian M, Mahjani MG, Gobal F, Danaee I (2006) Electrodeposition of aluminum from molten $\mathrm{AlCl}_{3}-\mathrm{NaCl}-\mathrm{KCl}$ mixture. J Appl Electrochem 36:1169

12. Fukumoto M, Suzuki T, Hara M, Narita T (2009) Effect of the electrodeposition temperature on the cyclic-oxidation resistance of $\mathrm{Ni}$ aluminide containing $\mathrm{Zr}$ formed by molten-salt electrodeposition. Mater Trans 50:335

13. Charrier C, Jacquot P, Denisse E, Millet JP, Mazille H (1997) Aluminium and Ti/Al multilayer PVD coatings for enhanced corrosion resistance. Surf Coat Technol 90:29

14. Yang D, Jonnalagadda R, Rogers BR, Hillman JT, Foster RF, Cale TS (1998) Texture and surface roughness of PRCVD aluminum films. Thin Solid Films 332:312-318

15. Paredes RSC, Amico SC, d'Oliveira ASCM (2006) The effect of roughness and pre-heating of the substrate on the morphology of aluminium coatings deposited by thermal spraying. Surf Coat Technol 200:3049-3055

16. Hussey TS, Koczak MJ, Smith RW, Kalidindi SR (1997) Synthesis of nickel aluminides by vacuum plasma spraying and exothermic in situ reactions. Mater Sci Eng A 229:137-146

17. Bose $S$ (2007) High temperature coatings. Elsevier Butterworth Heinemann, Oxford, pp 71-97

18. Houngninou C, Chevalier S, Larpin JP (2004) Synthesis and characterisation of pack cemented aluminide coatings on metals. Appl Surf Sci 236:256-269

19. Chu MS, Wu SK (2003) The improvement of high temperature oxidation of Ti-50Al by sputtering Al film and subsequent interdiffusion treatment. Acta Mater 51:3109-3120

20. Zhong D, Moore JJ, Disam J, Thiel S, Dahan I (1999) Deposition of $\mathrm{NiAl}$ thin films from NiAl compound target fabricated via combustion synthesis. Surf Coat Technol 120-121:22-27

21. Wang D, Shi Z, Zou L (2003) A liquid aluminum corrosion resistance surface on steel substrate. Appl Surf Sci 214:304-311

22. Kobayashi S, Yakou T (2002) Control of intermetallic compound layers at interface between steel and aluminum by diffusiontreatment. Mater Sci Eng A 338:44-53

\section{SN Applied Sciences}


23. Gálová M (1980) Electrodeposition of aluminium from organic aprotic solvents. Surf Technol 11:357-369

24. Zhao Y, VanderNoot TJ (1997) Electrodeposition of aluminium from nonaqueous organic electrolytic systems and room temperature molten salts. Electrochim Acta 42:3-13

25. Lehmkuhl H, Mehler K, Landau U, Gerischer H, Tobias CW (eds) (1994) The principles and techniques of electrolytic aluminum deposition and dissolution in organoaluminum electrolytes. In: Advances in electrochemical science and engineering, vol 3, VCH Publishers, New York, pp 163-226

26. Simka W, Puszczyk D, Nawrat G (2009) Electrodeposition of metals from non-aqueous solutions. Electrochim Acta 54:5307-5319

27. Aubron JJ, Barberio YL (1985) An ambient temperature secondary aluminum electrode: its cycling rates and its cycling efficiencies. J Electrochem Soc 132:598-601

28. Hurley FH, WierTP (1951) Electrodeposition of metals from fused quaternary ammonium salts. J Electrochem Soc 98:203-206

29. Endres F, El Abedin SZ (2006) Air and water stable ionic liquids in physical chemistry. Phys Chem Chem Phys 8:2101-2116

30. Chao- Cheng Yang (1994) Electrodeposition of aluminum in molten $\mathrm{AlCl}_{3}-\mathrm{n}$-butylpyridinium chloride electrolyte. Mater Chem Phys 37:355-361

31. Yue G, Lu X, Zhu Y, Zhang X, Zhang S (2006) Electrodeposition of aluminium from ionic liquids: part I-electrodeposition and surface morphology of aluminium from aluminium chloride $\left(\mathrm{AlCl}_{3}\right)$-1-ethyl-3-methylimidazolium chloride ([EMIm]CI) ionic liquids. Surf Coat Technol 201:1-9

32. Legrand L, Heintz M, Tranchant A, Messina R (1995) Sulfonebased electrolytes for aluminum electrodeposition. Electrochim Acta 40:1711-1716

33. Hirato T, Fransaer J, Celis J-P (2001) Electrolytic codeposition of silica particles with aluminum from $\mathrm{AlCl}_{3}$-dimethylsulfone electrolytes. J Electrochem Soc 148:C280-C283

34. Miyake M, Tajikara S, Hirato $\mathrm{T}$ (2011) Fabrication of $\mathrm{TiAl}_{3}$ coating on TiAl-based alloy by Al electrodeposition from dimethylsulfone bath and subsequent annealing. Surf Coat Technol 205:5141-5146

35. Jiang T, Brym MJC, Dube G, Lasia A, Brisard GM (2007) Studies on the $\mathrm{AICl} 3 /$ dimethylsulfone (DMSO2) electrolytes for the aluminum deposition processes. Surf Coat Technol 201:6309-6317

36. Legrand L, Tranchant A, Messina R (1994) Electrodeposition studies of aluminum on tungsten electrode from $\mathrm{DMSO}_{2}$ electrolytes. J Electrochem Soc 141:378-382
37. Legrand L, Tranchant A, Messina R, Romain F, Lautie A (1996) Raman study of aluminum chloride-dimethylsulfone solutions. Inorg Chem 35:1310-1312

38. Miyake $M$, Motonami $H$, Hirato $T$ (2012) Iron aluminide coatings by electrodeposition of aluminum from an organic bath and subsequent annealing. ISIJ Int 52:2273-2277

39. Shiomi S, Miyake M, Hirato T (2012) Electrodeposition of bright Al-Zr alloy coatings from dimethylsulfone-based baths. J Electrochem Soc 159:D225-D229

40. Fransaer J, Leunis E, Hirato T, Celis J-P (2002) Aluminium composite coatings containing micrometre and nanometre-sized particles electroplated from a non-aqueous electrolyte. J Appl Electrochem 32:123-128

41. Legrand L, Chassaing E, Chausse A, Messina R (1998) RDE and impedance study of anodic dissolution of aluminium in organic $\mathrm{AlCl}_{3} /$ dimethylsulfone electrolytes. Electrochim Acta 43:3109-3115

42. Gaylord Chemical Company, L.L.C. (2007) Dimethyl sulfone $\left(\mathrm{DMSO}_{2}\right.$ ) physical properties

43. Pereira-Ramos JP, Messina R, Perichon J (1986) Electrochemical formation of LiAl alloy in molten dimethylsulfone at $150^{\circ} \mathrm{C}$. J Electroanal Chem 209:283-296

44. Okamoto H, Miyake M, Hirato T (2014) Influence of water content on electrodeposition of aluminum from dimethylsulfone baths. J MMIJ 130:70-75

45. Hinton JF, Briggs RW (1978) In: Harris RK, Mann BE (eds) NMR and the periodic table. Academic Press, Cambridge, p 279

46. Akitt JW (1972) Nuclear magnetic resonance spectroscopy in liquids containing compounds of aluminium and gallium. Ann Rep NMR Spectrosc 5A:465-556

47. Kurayasu $H$, Inokuma $Y$ (1993) Determination of oxide ions in aluminum chloride-alkali chloride melts by Karl Fischer titration. Anal Chem 65:1210-1212

48. Miyake M, Motonami H, Shiomi S, Hirato T (2012) Electrodeposition of purified aluminum coatings from dimethylsulfone- $\mathrm{AlCl}_{3}$ electrolytes with trimethylamine hydrochloride. Surf Coat Technol 206:4225

49. Alhajeri SN, Gao N, Langdon TG (2011) Hardness homogeneity on longitudinal and transverse sections of an aluminum alloy processed by ECAP. Master. Sci. Eng. A 528:3833-3840

50. Huang F, Tao NR, Lu K (2011) Effects of Strain Rate and Deformation Temperature on Microstructures and Hardness in Plastically Deformed Pure Aluminum. J Mater Sci Technol 27:1-7 